九州大学学術情報リポジトリ

Kyushu University Institutional Repository

Applicability Estimation of Bioleaching into Copper Mining Industry: Comparison between Mining-Developed and Developing Countries

Oyama, Keishi

Graduate School of Engineering, Kyushu University

https://doi.org/10.5109/4055216

出版情報 : Evergreen. 7 (2)，pp.195-201，2020-06. 九州大学グリーンテクノロジー研究教育センター バージョン：

権利関係 : 


\title{
Applicability Estimation of Bioleaching into Copper Mining Industry: Comparison between Mining-Developed and Developing Countries
}

\author{
Keishi Oyama* \\ Graduate School of Engineering, Kyushu University, Japan \\ *Author to whom correspondence should be addressed: \\ E-mail: k-oyama14@mine.kyushu-u.ac.jp
}

(Received January 31, 2020; Revised April 17, 2020; accepted April 17, 2020).

\begin{abstract}
Chile and Indonesia, as a mining-developed country and a mining-developing country, respectively, are compared to estimate the future applicability of bioleaching technique into real operation. Chilean copper industry has improved via the following steps: (i) domination by foreign capitals, (ii) resource nationalization, (Chilenization), (iii) lost competitiveness due to the decrease in the ore-grade, (iv) the invitation of foreign capitals to regain the competitiveness. Indonesia takes the same path and it was easily predicted that Indonesian copper mining industry is also likely to loose the competitiveness due to the decrease in ore-grade. Therefore, the installation of bioleaching would be proposed for further development of Indonesian copper industry.
\end{abstract}

Keywords: bioleaching; mining; copper industry; Chile; Indonesia

\section{Introdution}

Copper $(\mathrm{Cu})$ is one of base metals, which is crucially important for the dairy life of human beings, basically used for such as coins, electrodes, wires, and alloys. Important resources of copper are obtained from the copper minerals such as copper oxides, chalcocite, and covellite, basically produced as a component of highgrade copper ore by mining. However, the reserves of high-grade copper ore have been dramatically depleted in decades, while the copper demand has been gradually increasing all over the world. Therefore, the novel technique to effectively obtain copper from low-grade copper ore has been desperately required.

For the process of high-grade copper ore, pyrometallurgy (extracting the metals from the ores by heating at high temperature) has been used due to its high effectiveness, while this process is inapplicable to the lowgrade copper ore from the economical point of view. Instead of pyrometallurgy, hydrometallurgy (extracting the metals from the ores by using the solvent such as acids) is considered as an effective process for low-grade ore due to its economical feasibility. As the application of hydrometallurgical process, microbiological techniques such as bioleaching (extracting the objective metals from the ores by using microbial iron (Fe)- and sulfur (S)oxidizing ability) and biooxidation (degrading the unwanted minerals by microbiological activity to increase the grade of objective minerals) have been well-studied and developed in mining area. The advantages to use these biomining techniques in mining area are summarized as follows: (i) metals can be obtained even from the lowgrade ore unused and left behind in previous mining operation or closed mine, (ii) biomining processes are more environmentally friendly than conventional smelting/refining operation due to the lower energy consumption and no toxic gas emission ${ }^{1}$. Since biomining has the advantages in low cost and low environmental impact ${ }^{2-5)}$, application of it in mining site has been considered to further develop the copper production industry.

Biomining (Biohydrometallugy) is one of the most successful and commercially enlarged biotechnology and heap bioleaching is the application of biomining in industry. The mined ores are piled onto the impermeable base to build a big heap, for example, $2400 \mathrm{~m}$ in the width, $800 \mathrm{~m}$ in the depth, and $15 \mathrm{~m}$ in the height ${ }^{6}$. Acid solution such as sulfuric acid is spread over the heap, which percolate the piled ores. During the percolation, inside of the heap becomes acidic condition, leading to activate microorganisms attached on the surface of ores. Consequently, Fe-oxidation and S-oxidation by microorganisms enhanced the dissolution of ores and pregnant liquor is obtained from the bottom of the heap.

Heap leaching has advantages from the economical viewpoint, such as simple installation, low capital cost, less maintenance, and reasonable yields over a period of circulation ${ }^{4}$. The capital cost of a bioleaching operation is considerably less, by about $50 \%$, than that of conventional smelting/refining operation. The production cost of heap 
leaching is a function of ore-grade and the total estimated cash cost was thus calculated as 1,087 US\$/ton for $0.4 \%$ ore-grade and 645 US\$/ton for $1.2 \%$ ore-grade, which are theoretically competitive with conventional smelting/refining process ${ }^{7}$. However, since the leaching rate of bioleaching is slower than that of conventional smelting/refining process, operation time would be longer. As a result, annual operating cost of bioleaching projects in Collahuasi, Chuquicomata, Salvador (within the range of 664 to 1,340 US\$/ton $\mathrm{Cu}$ ) became rather high than that of conventional processes (within the range of 650 to 880 US\$/ton $\mathrm{Cu})^{7}$ ). This observation indicates that bioleaching process would be required the continued reduction of operating cost by fastening the reaction rate and shortening the retention times to be competitive with conventional smelting process. Nevertheless, the application of bioleaching technique into industry is desperately desired since it enables the low-grade ores, which have been disposed so far, to be utilized as a valuable metal resource.

For sustainable copper supply in the world, the implementation of bioleaching into mining industry is likely to play an important role. In order to estimate the future applicability of bioleaching into copper mining, the objective of this study was set to investigate and compare the mining-developed and -developing countries. Chile and Indonesia therefore were chosen as a miningdeveloped and a mining-developing country, respectively, since the former is the world biggest copper supplier and several bioleaching plants have been actually implemented into copper industry, while the latter has no bioleaching plant in copper industry even though it has big copper mine with low-grade of ore. Through this comparison, the factors affecting the bioleaching implementation were clarified and the future applicability of bioleaching into copper industry was estimated.

\section{Chile: a mining-developed country}

\subsection{Copper industry in Chile}

Chile is the primary copper producer and produced approximately $30 \%$ of copper in the world in this decade (Fig. 1). While the proportion has been slightly decreasing in the past several years (27\% of world share in $2018^{8)}$ ), the contribution still has the crucial impact on the world copper supply (Fig. 2). The reserve of copper in Chile was reported to be approximately 170 million tons, which was estimated to be $22 \%$ of world copper reserves (790 million tons) ${ }^{9)}$. Chilean economy has the strong relationship with copper industry and $56 \%$ of its exports to the major trading partners such as Japan, China, the United States of America were occupied by mining industry in 2017 ${ }^{10)}$. Therefore, sustainable copper production and improvement of copper industry are necessary for Chilean economy.

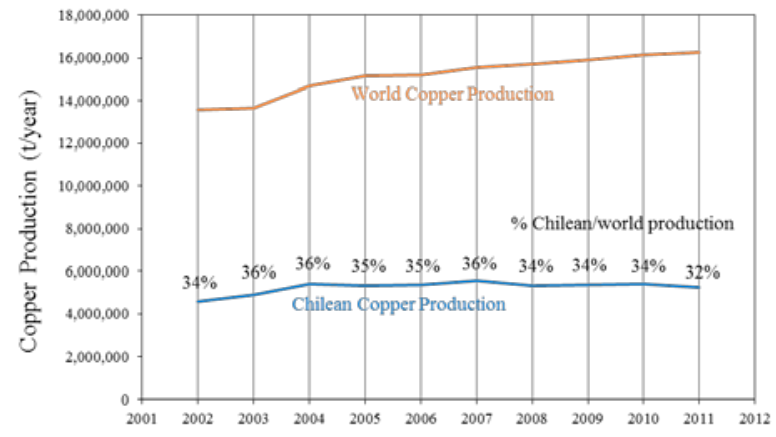

Fig. 1: World and Chilean copper production (modified) ${ }^{11)}$.

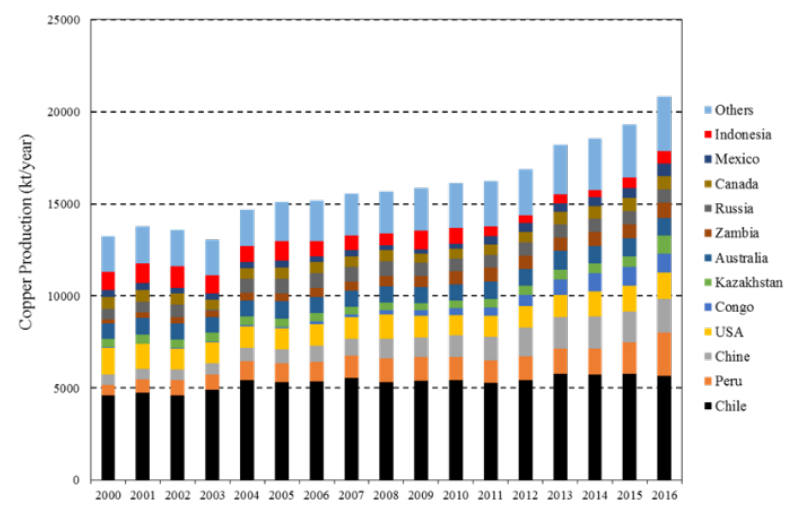

Fig. 2: Trend in world copper production.

Capital composition of major copper mine in Chile is summarized in Fig. 3. The main mining operator in Chile is not only Chilean state owned mining company such as Corporación Nacìnal del Cobre de Chile (CODELCO) but also private companies with foreign capital such as BHP Billition, Rio Tinto, Glencore, Anglo American, Freeport-McMoRan, Antofagasta Minerals, and some Japanese companies. The large copper mines in Chile have been mainly explored by domestic and foreign companies mentioned above, for example, Chuquicamata (CODELCO), Radomiro Tomic (CODELCO), Ministro Hales (CODELCO), Salvador (CODELCO), Andina (CODELCO), El Teniente (CODELCO), Los Pelambres (Antofagasta, Japanese companies), Escondida (BHP Billiton, Rio Tinto, Japanese companies), Collahuasi (Glencore, Anglo American, Japanese companies), and Los Bronces (Anglo American, CODELCO, Japanese companies). 


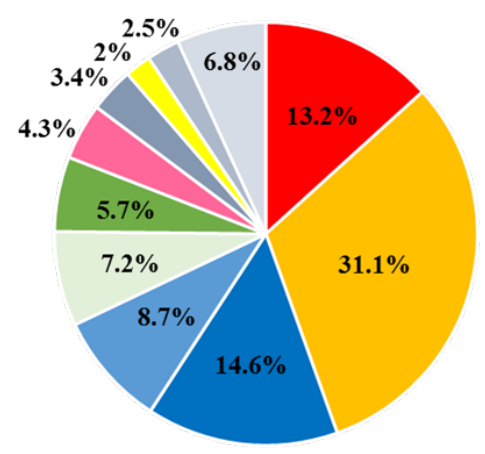

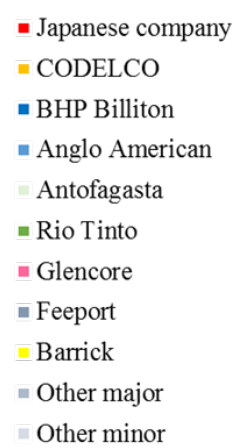

Fig. 3: Capital composition of major copper mine in Chile (modified) ${ }^{12)}$.

\subsection{Historical background of nationalization in copper industry (Chilenizacion)}

A trace of copper mining at the period of Spain's rule remains as the oldest one in Chile. The Spanish conquerors first found the Chilean metal resource potential and started the mining operation mainly focusing on the gold and silver but not copper exploitation ${ }^{13)}$. Fullblown copper mining operation started in early 1900's accompanied with the entry of American private company in Chilean copper industry. At this time, large-scale porphyry copper deposit such as Chuquicamata, El Teniente, and Salvador were explored by those companies, indicating that the Chilean copper industry was dominated by the United States of America. Even though the exploitation of copper by foreign capitals had been subsequently continued for a while, along with the rising "resource nationalism" (the tendency of people and government to assert control over natural resources located on their territory), Chilean government concluded a treaty that $20 \%$ of copper production is able to be managed by Chilean government in 1951 to overcome the squeezed situation. In 1955, the exclusive right that the United States of America decides the copper price was brought to the end by Chilean congress via legislating the Act No. 11828, called "new treatment law". After that, Chilean government have directly entered the copper industry and, in 1966, Act No. 16452 was legislated, which force the foreign companies to establish the Joint Venture whose $51 \%$ of share must be hold by Chilean government. Finally, Chilean congress decided the complete nationalization of copper industry by legislating the Act No. 17450 in 1971 and all interests of copper mines were completely transferred into governmentowned mining company. A series of action to exclude the foreign capitals from Chilean copper industry is called "Chilenizacion"14).

Since the CODELCO has been created as a state enterprise in 1976, the principal mines in Chile had been managed in one huge corporation. However, in 1980s, the competitiveness of CODELCO had been declined due to the decrease in copper ore-grade. Even though CODELCO had tried to regain the competitiveness by modernizing the management and concentrating the production ability in 1990s, Act No. 19137, "Law of Joint Ventures with third Parties”, was legislated in 1992, which enabled CODELCO to establish the Joint Venture with domestic and foreign companies for more flexible copper production. Consequently, the era of Chilean exclusive operation in copper industry was brought to the end.

\subsection{Historical development of bioleaching in Chile}

Chile is the first country installing the bioleaching of copper sulfide into commercial operation in the world and a number of bioleaching plant have been implemented into real operation so far. The commercial bioleaching operations and the increase in the copper production by bioleaching operation in Chile are summarized in Table 1

Table 1: The list of commercial bioleaching operation in Chile (modified) $5,11,15,16$ ).

\begin{tabular}{|l|l|c|c|c|}
\hline \multicolumn{1}{|c|}{ Mine } & \multicolumn{1}{c|}{ Operator } & Production t/year & Ore grade \% & $\begin{array}{c}\text { Period of } \\
\text { operation }\end{array}$ \\
\hline Lo A guirre & Sociedad Minera Pudahuel & 15,000 & 1.5 & $1980-1996$ \\
\hline Lince II & Antofagasta Plc & 27,000 & n.d. & $1991-2009$ \\
\hline Cerro Colorado & BHP Billiton & 100,000 & 1.0 & 1993 -present \\
\hline Ivan-Zar & Compañía Minera Milpro & 12,000 & 2.1 & 1994 -present \\
\hline Punta del Cobre & Sociedad Punta del Cobre, S.A. & 8,000 & n.d. & 1994 -present \\
\hline Quebrada Blanca & Aur Resources & 82,000 & 0.9 & 1994 -present \\
\hline Chuquicamata & CODELCO & 12,500 & 0.3 & 1994 -present \\
\hline Andacollo & Aur Resources & 22,500 & 0.6 & 1996 -present \\
\hline Dos Amigos & CEMIN & 10,000 & 2.5 & 1996 -present \\
\hline Zaldivar & Barrick & 147,000 & 1.4 & 1998 -present \\
\hline Lomas Bayas & Glencore Plc & 60,000 & n.d. & 1998-present \\
\hline Los Bronces & Anglo-A merican & 46,400 & 0.5 & 2006 -present \\
\hline Escondida & BHP Billiton & 180,000 & $0.3-0.7$ & 2006 -present \\
\hline Spence & BHP Billiton & 120,000 & 1.1 & 2007 -present \\
\hline Collahuasi & Xstrata & 60,000 & n.d. & n.d. \\
\hline Radomiro Tomic & CODELCO & 100,000 & n.d. & 2010-present \\
\hline Andina & CODELCO & 25,000 & n.d. & 2011-present \\
\hline
\end{tabular}




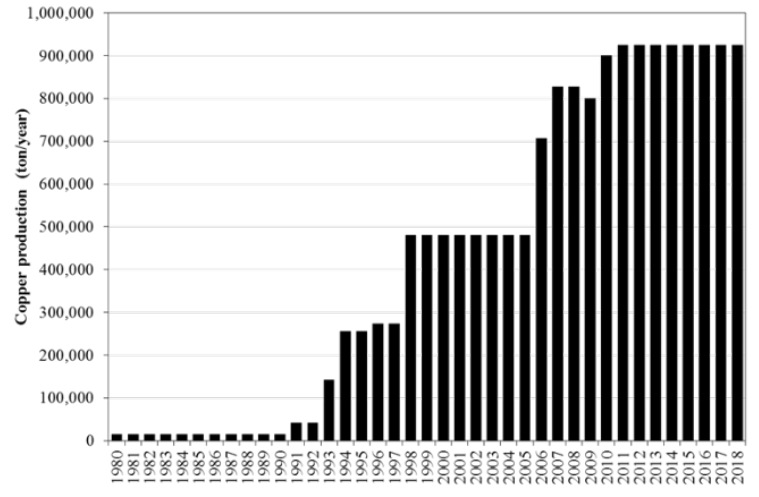

Fig. 4: Estimation of the copper production by bioleaching in Chile calculated from the Table 1.

and Fig. 4. It is obvious that some part of copper industry in Chile is supported by bioleaching technique and it is assumed that the contribution by bioleaching would continue to further increase.

In the era from late 1960s to early 1970s, the first registered studies regarding one microorganism, Acidithiobacillus ferrooxidans, which is likely to be useful for mining operation, was carried out by Manuel Rodriguez at the Faculty of Biological Sciences of the Pontificia Universidad Católica de Chile and Claudio González at the Faculty of Chemistry and Pharmacy at the Universidad de Chile ${ }^{13)}$. However, at this time, their interest is not on the usage of bacteria in the mining industry but on the basic microbiology. In the early 1970s, the Chilean government also started the research on the bacterial leaching by establishing two research institutes: The Centro de Instituto de Investigaciones Tecnológical (CIMM; Mining and Metallurgical Research Center) and the Instituto de Incestigaciones Tecnológical (INTEC; Technological Research Institute $)^{17)}$. Since this establishment, the application of bioleaching technique has been actively studied.

The research on the implementation of bioleaching to industrial systems was accelerated by CODELCO in order to regain the lost competitiveness due to the lowering oregrade, since bioleaching operation is appropriate for the exploitation of low-grade ore. In 2000, after establishment of a joint venture with foreign companies are allowed by Act No. 19137, Alliance Copper Company was founded by joint investment with BHP Billiton to construct the pilot plant of copper-concentrate bioleaching. In the following year, Biosigma S.A. was also founded with JX Nippon Mining \& Metals Corporation to develop the bioleaching technique of copper sulfides. These two companies successfully improved the bioleaching technique in Chile; Alliance Copper started the operation of prototype plant in 2003 and Biosigma found the new Sand Fe-oxidizing bacterial which can be used for bioleaching in 2004 ${ }^{12}$. However, the construction of commercial scale bioleaching plant, which was designed based on the prototype plant of Alliance Copper, was abandoned from the economical point of view.
Nevertheless, CODELCO further promoted the construction of new bioleaching test plant in Andina mine and succeeded the production of copper cathode in the new plant in 2007. Afterwards, new bioleaching operation was actively installed into the real operation, for example, in Radomiro Tomic mine with the largest bioleaching plant in the world. Nowadays, $10 \%$ of copper production in Chile has been contributed by bioleaching operation ${ }^{13)}$.

\section{Indonesia: a mining-developing country}

\subsection{Copper industry in Indonesia}

Indonesia is rich in mineral resources such as coal, copper gold and other metals and the value of mineral commodity production accounts for $10.5 \%$ of the GDP, indicating that the sustainable mining industry is important business even in Indonesia. The main trading partners are Asian countries, such as China, Korea, and Japan. Even though the annual copper production in Indonesia is rather small than that in Chile (666.3 thousands ton in 2017) ${ }^{18)}$, this country possesses the second largest mine on cupper production capacity, Grasberg (Fig. 5), which is also known as the largest gold mine in the world ${ }^{19)}$. Therefore, this country has the potential to change from a mining-developing country to a mining-developed country.

The capital composition of major copper mine in Indonesia, Grasberg and Batu Hijau, are listed in Table 2. Currently, the mining operator of Grasberg mine is PT Freeport Indonesia (PTFI), whose operation right would be transferred to the Indonesian government-owned company, PT Inalum, by 2041. While the capital of Batu Hijau mine had been possessed by foreign capitals such as Newmont Mining and Japanese companies until 2016, and then the all capitals transferred to PT Amman Mineral International and the mining operation of this mine was completely under Indonesian government control. These capitalization of Indonesian mines by domestic companies is due to the dynamic change of Indonesian government policy.

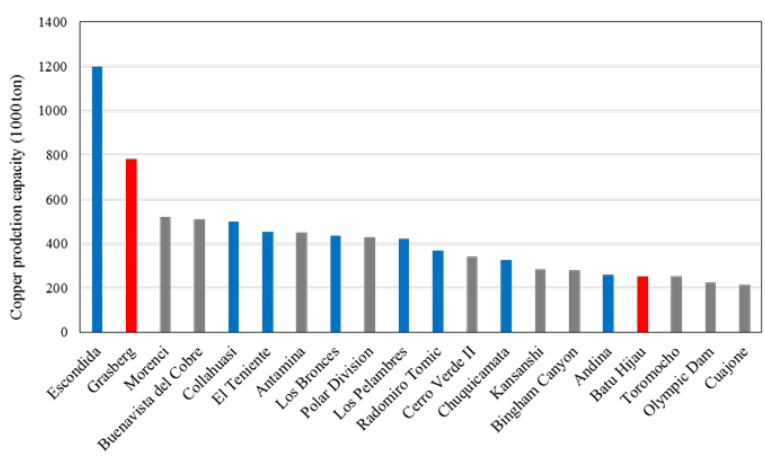

Fig. 5: Copper mine in the world: Top 20 on copper production capacity (red: Indonesian mine, blue: Chilean mine) ${ }^{20)}$. 
Table 2: Capital composition of major copper mine in Chile and Indonesia. Blue and red colors indicate the domestic company ${ }^{18)}$ in Chile and Indonesia, respectively.

\begin{tabular}{|c|c|c|}
\hline Mine & Country & Owner(s) \\
\hline Escondida & & BHP Billiton 57.5\%, Rio Tinto Corp. 30\%, Japanese company $12.5 \%$ \\
\hline Collahuasi & & Anglo American $44 \%$, Glencore $44 \%$, Japanese companies $12 \%$ \\
\hline El Teniente & & Codelco $100 \%$ \\
\hline Los Bronces & Chile & Angle American 50.1\%, Codelco 20\%, Japanese companies $29.9 \%$ \\
\hline Los Pelambres & conle & Antofagasta $60 \%$, Japanese companies $40 \%$ \\
\hline Radomiro Tom ic & & Codelco $100 \%$ \\
\hline Chuquicamata & & Codelco $100 \%$ \\
\hline Andina & & Codelco $100 \%$ \\
\hline Grasberg & Indonesia & $\begin{array}{l}\text { P.T. Freeport Indones ia Co. (PTFI) } 90.64 \% \rightarrow 49 \% \text {, Indonesia government } 9.36 \% \rightarrow \text { PT } \\
\text { Inalum } 51 \%\end{array}$ \\
\hline Batu Hijau & & PT Amman Mineral International $82.2 \%$, PT Pukuafu Indah $17.8 \%$ \\
\hline
\end{tabular}

\subsection{Historical background of mining industry and its nationalization}

The mineral industry in Indonesia has a long history and the foundation of the today's industry was made by Dutch, who had explored between 1840s and 1930s ${ }^{22)}$. While Indonesia was the second largest producer of tin (Sn) during this period, due to the World War II and the capitalization by foreign enterprises, the production of the most minerals were dropped back to the pre-war level. In 1967, the new government carried out the sweeping changes of the policy in the mining industry by introducing a Foreign Capital Investment Law and revising the Mining Law. Based on this change, foreign capitals were permitted to operate the mining work under the "Contract of Work (COW)" system (foreign companies have to make a contract with not mine owner but with Indonesian government). As a feature of this system, the exploring mine have to be stepwisely capitalized by Indonesian government or companies in order to nationalize the Indonesian mine by themselves along with the rising of resource nationalization. This COW has been revised several times and there are 7 generations of COW with varied contents.

When Indonesia started to invite the foreign companies to mining industry with COW, the foreigners were mainly interested in the existing mines found by the Dutch, such as Ertsberg mine (copper) in Irian, Jaya. Freeport Sulfur, foreign company with American capital, signed to the first generation COW for the exploration of Ertsberg mine in 1967, which contained the following articles: (i) operation period was 30 years, (ii) the term of the tax exemption was 3 years and $35 \%$ of the corporate income tax was reduced, (iii) royalties on copper and gold were exempted, (iv) the full control and the management of exploration and mining operations were permitted ${ }^{21)}$. This Freeport's agreement directed the other mining companies toward Indonesian mining business and the second generation COW was signed by the other foreign capitals, which is more onerous than the first generation' one.

In 1970, Freeport Sulfur started the mining operation in Ertsberg and the company name changed from Freeport Sulfur to Freeport Minerals in the following year ${ }^{22)}$. In 1982, Freeport Minerals merged with McMoRan Oil \&
Gas, the mining company producing the oil, gas, and uranium, resulting in the establishment of Freeport McMoran Inc. (FTX). In 1988, this FTX divided the 20\% of copper mining interests in Indonesia to established new company, Freeport McMoRan Copper, which seize the control of Indonesian blanch of FTX, PT Freeport Indonesia Co. (PTFI). In the same year, the most important mine for Indonesian industry, Grasberg mine, was found nearby the Ertsberg mine and its operation started in the following year. The company name of Freeport McMoRan Copper was changed to FCX that revised the COW to obtain the interests of Grasberg mine for 30 years' mining operation including the twice 10 years' extension option (in total, 30 years). Since this, exploitation of Grasberg mine has been mainly operated by PTFI to this day.

Since 2005, the Mining Law has been revised to resolve an issue based on consistency with other laws; thus the discussion about the new Mining law had begun in 2005. While it had taken more than 3 years to be reach a consensus, on January 2009, new Mining Law “Act No. 4 regarding the mining of minerals and coals" was enforced $^{23)}$. The features of this new law were as follows: (i) COW system was abolished and mining operator must get the permission from Indonesian government but not make a contract to obtain the mining rights, (ii) the power of giving permission was mostly transferred from the central government to local government for the decentralization, (iii) along with the rising resource nationalization, high value-added on the production and Indonesian capitalization were strictly required. After new Mining Law was enforced, some Cabinet Orders and Ministerial Decree have been also enacted since 2009 to 2012, which were not appropriately consistent with new Mining Law. Especially, the exportation of mining ore was prohibited by the Ministerial Decree of Energy and Mineral Resource 2012 No.7 enforced on February 2012, leading to the harsh situation for the mining operation by foreign companies in Indonesia. Finally, the exportation of all untreated minerals had been completely prohibited on January, 2014. As a transitional measure for this situation, the concentrates as the intermediate products had been permitted to be exported until 2017. When the 
transitional measure ended, in January 2017, Indonesian government further revised the governmental ordinance, which enables the mining companies to export the concentrates and ores for the limited time as 5 years. At the same time, all foreign companies, without any exemption, must take a responsibility to transfer the 51\% of mining interests to the domestic capitals within 10 years ${ }^{24-26)}$. This revision of governmental ordinance indicated that all mining operation in Indonesia would be conducted by domestic companies, which is under the control of Indonesian government, forcing the foreign capitals to withdraw from the Indonesian mining industry.

As the result of these subsequential policy change in Indonesia, in June 2016, the major mining operators, Newmont Mining and Sumitomo Corporation, transferred their interests of Batu Hijau mine to Indonesian domestic company, PT Amman Mineral International, in order to withdraw from the copper mining industry. PTFI, which is the current main operator of Grasberg mine, reached the basic agreement on the negotiation with Indonesian government, and was permitted to operate in the mine continuously until 2041. After this period, the 51\% interests of Grasberg mine must be transferred to Indonesian domestic company, PT Inalum ${ }^{27-28)}$. This interest transfer indicates that main conductor of Grasberg mining operation would not be PTFI but Indonesian domestic company, and thus the most copper mining in Indonesia would be consequently nationalized.

\section{Comparison between Chile and Indonesia to predict the bioleaching implementation}

Based on the comparison of historical background between two countries, it is easily found that Indonesia have been following in Chilean path. From this trend, it can be predicted that Indonesian mining industry will further follow in Chilean path as (i) the competitiveness was lost due to the decrease in the ore-grade, (ii) the invitation of foreign capitals would be permitted, for example, the establishment of joint venture companies. Indeed, copper ore-grade obtained in major copper mine in Indonesian is as low as that of Chilean mines (Table 3). This suggests Indonesian domestic companies might lose the competitiveness to manage the all copper mines in Indonesia, possibly resulting in the invitation of foreign capitals again to obtain the sufficient financial support and expert techniques.

When the CODELCO faced to the problems on the decrease in the ore-grade, bioleaching technology have been actively studied in Chile for its implementation into real operation since the technique is applicable even for the exploitation of low-grade copper ores. As shown in Table 3, the copper ore-grade of Grasberg mine in Indonesia is as low as that of Chilean mine, implying that the installation of bioleaching technique is considered as a necessary countermeasure for further development of copper industry in Indonesia. Actually, bioleaching operation contributes to $10 \%$ of current copper production in Chile ${ }^{13)}$, which prove the effectiveness of installation of bioleaching into copper mining industry (Fig. 4).

Table 3: Copper ore-grade in major copper mine in Chile and Indonesia ${ }^{22,29,30)}$.

\begin{tabular}{|c|c|}
\hline Mine & $\begin{array}{c}\text { Copper grade of } \\
\text { ore (\%) }\end{array}$ \\
\hline Grasberg (Indonesia) & 0.97 \\
\hline Radomiro Tomic (Chile) & 0.36 \\
\hline Chuquicamata (Chile) & 0.48 \\
\hline Salvador (Chile) & 0.47 \\
\hline Andina (Chile) & 0.60 \\
\hline Escondida (Chile) & 0.47 \\
\hline Spence (Chile) & 0.96 \\
\hline
\end{tabular}

\section{Summary}

The historical backgrounds of mining-developed country, Chile, and mining-developing country, Indonesia, were compared from mainly political point of view to predict the future applicability of bioleaching into real operation. The common historical steps of these countries were as follows: (i) mining industry was dominated by foreign capitals, (ii) the thought of resource nationalization rose, (iii) mining operation was completely nationalized. After these periods, while the competitiveness of CODELCO, Chilean government-owned mining company, once became low due to the decrease in the copper oregrade, as a mining-developed country, Chile installed the bioleaching technique into copper mining industry to overcome this situation. Nowadays, ten\% of copper industry in Chile is contributed by bioleaching operation, which proves the effectiveness of the installation of bioleaching technique into real operation. Seen from these historical steps, it is predicted that the Indonesian government/domestic companies would be necessitated to implement the bioleaching operation into copper industry since it is assumed that they would also lose the competitiveness due to the decrease in copper ore-grade, which is not future problems but current situation in Indonesia. In order to transition from the miningdeveloping country to mining-developed country, the application of bioleaching technique into copper industry in Indonesia is inevitable which surely enhance the competitiveness of Indonesia as a copper producer in the world. 


\section{References}

1) D.E. Rawlings, D. Dew, and C.K. du Plessis, Trends in Biotechnology, 21, 38-44 (2003).

2) J.A. Brierley and C.L. Brierley, Hydrometallurgy, 59, 233-239 (2001).

3) F. Acevedo, Electronic Journal of Biotechnology, 5, no.2 (2002).

4) N. Pradhan, K.C. Nathsarma, K. Srinivasa Rao, L.B. Sukla, and B.K. Mishra, Minerals Engineering, 21, 355-365 (2008).

5) S. Panda, A. Akcil, N. Pradhan, and H. Deveci, Bioresource Technology, 196, 694-706 (2015).

6) K. Sasaki and C. Tokoro, Journal of MMIJ, 127, 724 (2011).

7) H. Qilliam, Producing Copper Nature's Way: Bioleaching (2004), available at https://www.copper.org/publications/newsletters/inn ovations/2004/05/producing_copper_natures_way_b ioleaching.html (March 30, 2020).

8) JOGMEC, Trends in the world of mining 2018: Chile (2018), available at http://mric.jogmec.go.jp/wpcontent/uploads/2018/12/trend2018_cl.pdf (March 30, 2020).

9) USGS, Mineral commodity summaries 2018, 53, (2018), available at https://minerals.usgs.gov/minerals/pubs/mcs/2018/m cs2018.pdf (March 30, 2020).

10) JETRO, World trade and investment report 2018: Chile (2018), available at https://www.jetro.go.jp/ext_images/world/gtir/2018/ 27.pdf (March 30, 2020).

11) J.C. Gentina and F. Acevedo, Electric Journal of Biotechnology, 16, no.3 (2013).

12) JOGMEC, Metal resource repors, 1503-02-vol.44 (2015), available at http://mric.jogmec.go.jp/wpcontent/old_uploads/reports/resources-report/201503/vol44_No6_02.pdf (March 30, 2020).

13) J.C. Gentina and F. Acevedo, Minerals, 6, (2016).

14) JOGMEC, Trends of mineral resource majors 2010: CODELCO (2011), available at http://mric.jogmec.go.jp/wpcontent/old_uploads/reports/report/201109/codelco2010.pdf (March 30, 2020).

15) C.L. Brierley, Transactions of Nonferrous Metals Society of Chine, 18, 1302-1310 (2008).

16) C.S. Ghan, H. Srichandan, D.J. Kim, and A. Akcil, Research Journal of Recent Sciences, 1, 85-99 (2012).

17) M. Tanaka, Evergreen, 4, 1-7 (2017).

18) JOGMEC, Trends in the world of mining 2018: Indonesia (2018), available at http://mric.jogmec.go.jp/wpcontent/uploads/2018/10/trend2018_id.pdf (March 30, 2020).

19) P.A. Rifai-Hasan, Journal of Business Ethics, 89, 129-143 (2009).

20) JOGMEC, Transition in copper business -after
2000- (2018), available at http://mric.jogmec.go.jp/wpcontent/uploads/2018/12/report_cu_business201803 _revised2.pdf (March 30, 2020).

21) T.M. van Leeuwen, Journal of Geochemical Exploration, 50, 13-90 (1994).

22) JOGMEC, Trends of mineral resource major 2012: FCX: Freeport-McMoRan Copper \& Gold Inc. (2012), available at http://mric.jogmec.go.jp/public/report/201302/FCX_2012.pdf (March 30, 2020).

23) JOGMEC, Metal resource reports, 1801-01-vol. 47 (2018), available at http://mric.jogmec.go.jp/wpcontent/uploads/2018/01/mr201801_01.pdf (March 30, 2020).

24) JOGMEC, Metal resource reports, 1707-03-vol.47 (2017), available at http://mric.jogmec.go.jp/wpcontent/uploads/2017/08/mr201707_03.pdf (March 30, 2020).

25) JOGMEC, Metal resource reports, 1709-01-vol.47 (2017), available at http://mric.jogmec.go.jp/wpcontent/uploads/2017/09/mr201709_01.pdf (March 30, 2020).

26) JOGMEC, Metal resource reports, 1711-01-vol.47 (2018), available at http://mric.jogmec.go.jp/wpcontent/uploads/2017/11/mr201711_01.pdf (March 30, 2020).

27) JOGMEC, Current topics, No. 18-21 (2018), available at http://mric.jogmec.go.jp/reports/current/20180824/8 8779/ (March 30, 2020).

28) JOGMEC, Current topics, No. 19-07 (2019), available at http://mric.jogmec.go.jp/reports/current/20190226/1 11465/ (March 30, 2020).

29) JOGMEC, Trends of mineral resource major 2012: CODELCO (2012), available at http://mric.jogmec.go.jp/wpcontent/old_uploads/reports/report/201302/CODELCO_2012.pdf (March 30, 2020).

30) JOGMEC, Trends of mineral resource major 2012: BHPB: BHP Billiton Ltd. / BHP Billiton plc. (2012), available at http://mric.jogmec.go.jp/wpcontent/old_uploads/reports/report/201302/BHPB_2012.pdf (March 30, 2020). 